\title{
Penambahan Tepung Daun Sirsak (Annona muricata Linn) dalam Ransum terhadap Sistem Pencernaan Ayam Petelur Jantan (Gallus domesticus)
}

\section{Addition of Sirsak Leaf Powder in the Ration on Digestive System in Male Laying Hens (Gallus domesticus)}

\author{
R. Novita* dan W. Ibrahim \\ Prodi Peternakan Fakultas Pertanian Universitas Musi Rawas, Jl. Sultan Badaruddin II Kel. Air Kuti I, \\ Lubuklinggau-31628 - Indonesia \\ *Corresponding E-mail: novitaririn91@yahoo.com
}

(Diterima: 19 September 2019; Disetujui: 23 November 2019)

\begin{abstract}
ABSTRAK
Penelitian ini bertujuan untuk mengetahui Penambahan Tepung Daun Sirsak dalam Ransum Terhadap sistem pencernaan Ayam Petelur Jantan (Gallus domesticus). Metode penelitian yang digunakan adalah metode eksperimental dengan menggunakan Rancangan Acaka Lengkap (RAL) yang disusun secara non faktorial, dengan 6 taraf perlakuan 4 kali ulangan sehingga diperoleh 24 unit percobaan. Adapun perlakuan dalam penelitian ini adalah : U0 = Pakan komersil BR-1, U1 = 100\% Pakan Komersil Tanpa Tepung Daun Sirsak, U2 = Pakan Komersil 98\% + Tepung Daun Sirsak 2\%, U3 = Pakan Komersil 96\% + Tepung Daun Sirsak 4\%, U4 = Pakan Komersil 94\% + Tepung Daun Sirsak 6\%, U5 = Pakan Komersil 92\% + Tepung Daun Sirsak 8\%. Dari hasil analisis data secara statistik diketahui bahwa perlakuan pemberian tepung daun sirsak dalam ransum terhadap sistem pencernaan ayam Petelur Jantan tidak berpengaruh nyata terhadap bobot potong, bobot gizard, bobot usus halus dan bobot usus besar. Dari hasil penelitian dapat disimpulkan bahwa pemberian tepung daun sirsak pada taraf $8 \%$ dalam ransum mempengaruhi sistem pencernaan ayam petelur jantan.
\end{abstract}

Kata kunci: ayam petelur jantan, sistem pencernaan, tepung daun sirsak

\begin{abstract}
This study aims to determine the addition of the sirsak leaf powder in the Ration on the digestive system of Laying Hens (Gallus domesticus). The research method used was an experimental method using a Complete Randomized Design (CRD) arranged non-factorial, with 6 levels of treatment 4 replications so that 24 units of the experiment were obtained. The treatments in this study were: U0 = commercial feed BR-1, U1 $=100 \%$ commercial feed without soursop leafflour, U2 = commercial feed 98\% + soursop leaf flour 2\%, U3 = commercial feed 96\% + soursop leafflour $4 \%$, U4 = Commercial Feed 94\% + Soursop Leaf Powder 6\%, U5 = Commercial Feed 92\% + Soursop Leaf Powder 8\%. From the results of statistical analysis, it was found that the treatment of soursop leaf meal in the ration on the digestive system of Male Laying hens did not significantly affect cutting weight, gizzard weight, small intestine weight, and large intestine weight. The result showed that determine the effect of soursop leaf flour up to 8\% with addition was an effect on the digestive system of Laying Hens.
\end{abstract}

Keywords: digestive system, laying hens, soursop leaf flour

\section{PENDAHULUAN}

Populasi ayam ras petelur semakin meningkat dari tahun ke tahun dikarenakan semakin meningkatnya permintaan masyarakat akan telur konsumsi. Namun peningkatan populasi ini belum diiringi dengan peningkatan produktivitas ayam petelur. Oleh karena itu perlu dilakukan usaha untuk meningkatkan produktivitas ayam 
petelur, salah satunya melalui perbaikan sistem pemeliharaan. Kandang merupakan tempat ternak melakukan aktivitas produksi, sehingga kenyamanan dan bentuk kandang perlu diperhatikan supaya ternak merasa nyaman dan tidak mengganggu proses produksi (Sudarmono, 2003).

Ayam membutuhkan setidaknnya senyawa kimia esensial yang harus ada dalam ransum ayam. Senyawa kimia tersebut harus dalam jumlah yang cukup dalam perbandingan optimum satu terhadap lainnya dan dalam bentuk yang mudah di dapat untuk merangsang pertumbuhan laju maksimum, produksi telur. Apabila hal tersebut kurang di perhatikan oleh peternak maka pertumbuhan ayam, produksi akan turun dan ayam akan mudah terserang penyakit (Anggorodi, 2000).

Kebutuhan pakan memerlukan biaya sekitar $60-70 \%$ dari total biaya produksi (Rasyaf, 2006). Hal ini mengakibatkan rendahnya efisiensi produksi ayam petelur yang disebabkan oleh tingginya harga pakan, sehingga sering dilakukan upaya untuk mencampur pakan komersil dengan menambahkan pakan tambahan dari herbal yang dapat meningkatkan produksi. Salah satu pakan tambahan yang bisa dimanfaatkan adalah daun sirsak. Daun sirsak merupakan salah satu tanaman herbal yang diketahui mengandung senyawa flafonoid, alkaloid, acetogenin, annona asimisin, saponin, dan annona bulatacin (Adri, 2013).

Penelitian di Korea menemukan senyawa kimia yang berperan selektif membunuh sel kanker usus besar serta 10.000 kali lebih berpotensi sebagai obat kemoterapi. Disamping memiliki potensi yang sangat besar sebagai obat kemoterapi, senyawa kimia yang ada dalam daun sirsak bersifat selektif memilih sel target kanker sehingga tidak merusak sel-sel yang sehat (Rusmiyati, 2010).

Namun penggunaan daun sirsak sebagai pakan tambahan untuk ternak termasuk ayam belum banyak diketahui. Untuk mengetahui pengaruh penggunaan daun sirsak sebagai pakan tambahan dilakukan penelitian tentang penggunaan tepung daun sirsak terhadap produktifitas ternak khususnya ayam pedaging yang antara lain ditunjukan oleh perkembangan berat organ dalamnya. Dengan berkembangnya organ dalam yang baik khususnya yang terkait dengan fungsi pencernaannya, diharapkan metabolisme zat makan dalam tubuh ayam dapat berjalan dengan baik sehingga pertumbuhan ayam menjadi optimal (Rasyaf, 2006).

Berdasarkan penelitian yang telah dilakukan oleh Nur Rohmah et al. (2016) dapat disimpulkan bahwa penambahan tepung daun sirsak (Annona muricata Linn.) dalam pakan mampu meningkatkan bobot usus dan gizzard, serta menurunkan bobot sekum dan pankreas itik tegal jantan umur 10 minggu. Setiap penambahan tepung daun sirsak (Annona muricata Linn.) 1\%, maka bobot gizzard akan meningkat sebesar $0,07 \%$ dan bobot usus meningkat sebesar $0,4 \%$. Berdasarkan penjelasan di atas, peneliti tertarik untuk melaksanakan penelitian dengan judul "Pengaruh Pemberian Tepung Daun Sirsak (Annona muricata Linn.) dalam Ransum Terhadap Sistem Pencernaan Ayam Petelur Jantan".

\section{METODE}

\section{Tempat dan Waktu}

Penelitian ini telah dilaksanakan di Kelurahan Sumber Harta, Kecamatan Sumber Harta, Kabupaten Musi Rawas dengan ketinggian 129 mdpl dari Bulan Desember 2018 sampai Februari 2019.

\section{Bahan dan Alat}

Adapun bahan yang di gunakan dalam penelitian ini, yaitu 1) DOC Ayam Petelur Jantan sebanyak 96 ekor, 2) Tepung Daun Sirsak, 3) Pakan komersil ,4) dedak, 5) Jagung, 6) Air Minum, 7) Gula Putih, 8) Antibiotik, 9) Serbuk Gergaji, 10) Kayu, 11) Seng, 12) Desinfektan berupa Antiseptik. Sedangkan alat yang digunakan dalam penelitian ini, yaitu 1) Kandang panggung dengan ukuran $60 \mathrm{~cm} \mathrm{x}$ 
Tabel 1. Komposisi dan kandungan zat makanan ransum perlakuan

\begin{tabular}{lcccccc}
\hline \multirow{2}{*}{ Bahan Pakan } & \multicolumn{7}{c}{ Ransum } \\
\cline { 2 - 7 } & U0 & U1 & U2 & U3 & U4 & U5 \\
\hline Pakan komersil (\%) & 100 & 95 & 93 & 91 & 89 & 87 \\
Jagung (\%) & 0 & 3 & 3 & 3 & 3 & 3 \\
Dedak (\%) & 0 & 2 & 2 & 2 & 2 & 2 \\
Tepung daun sirsak (\%) & 0 & 0 & 2 & 4 & 6 & 8 \\
\hline Jumlah (\%) & 100 & 100 & 100 & 100 & 100 & 100 \\
\hline Kandungan Nutrisi: & & & & & & \\
Bahan kering (\%) & 99,28 & 99,00 & 98,79 & 98,29 & 98,04 & 98,04 \\
Protein kasar (\%) & 20,59 & 21,96 & 20,42 & 20,26 & 20,18 & 20,17 \\
Serat kasar (\%) & 4,17 & 4,65 & 5,14 & 6,12 & 6,60 & 6,60 \\
Lemak kasar (\%) & 6,06 & 6,03 & 6,01 & 5,96 & 5,93 & 5,93 \\
Energy metabolism (kkal/kg) & 3.144 & 3.084 & 3.024 & 2.994 & 2.904 & 2.884 \\
\hline
\end{tabular}

$76 \mathrm{~cm} \times 50 \mathrm{~cm}, 2)$ Tempat Pakan, 3) Tempat minum, 4) Thermometer, 5)Lampu Pijar 5 watt,6) Kabel, 7) Timbangan Kapasitas 2 kg, 8) Gergaji, 9) Paku, 10) Palu, 11) Meteran, 12) Kamera, 13) Blender, 14) Gunting, 15) Spidol, 16) Alas Litter, 17) Tali Plastik,18) Plastik 2kg, 19) Baskom, 20) sapu, 21) Tang Semprot, dan 22 ) Alat Tulis.

\section{Metode Penelitian}

Metode penelitian yang digunakan adalah metode eksperimental dengan menggunakan Rancangan Acak Lengkap (RAL Non Faktorial) dengan perlakuan penggunaan tepung daun sirsak. Penelitian ini terdiri dari 6 taraf perlakuan 4 kali ulangan sehingga diperoleh 24 unit percobaan, setiap unit percobaan (tiap kandang) diisi 4 ekor ayam petelur jantan. Sehingga pada penelitian ini diperlukan 96 ekor anak ayam petelur jantan (DOC). Susunan perlakuan penelitian ini dapat dilihat pada Tabel 1. Perlakuan yang akan dicobakan dalam penelitian ini adalah sebagai berikut:

$\mathrm{U} 0=$ Pakan komersil BR-1

U1 $=100 \%$ Ransum Basal Tanpa Tepung Daun Sirsak

U2 =Tepung Daun Sirsak 2\% dalam Ransum U3 =Tepung Daun Sirsak 4\% dalam Ransum U4= Tepung Daun Sirsak 6\% dalam Ransum
U5 = Tepung Daun Sirsak 8\% dalam Ransum

\section{Cara Kerja}

\section{Persiapan Kandang}

Kandang yang digunakan dalam penelitian ini adalah kandang panggung sistem litter yang di buat petakan yang beralas serbuk gergaji. Petakan yang dibuat sebanyak 24 petak, setiap petakan berukuran panjang 60 $\mathrm{cm}$, lebar $76 \mathrm{~cm}$, dan tinggi $50 \mathrm{~cm}$. Dinding petakan terbuat dari papan yang tipis. Masing - masing petakan dialasi dengan plastik dan kemudian diberi serbuk gergaji dengan ketebalan $5 \mathrm{~cm}$ dan di pasangkan lampu pijar 5 watt, tempat pakan dan tempat minum. Selain itu di kandang pemeliharaan juga dilengkapi dengan termometer ruangan untuk mengukur suhu ruangan yang ada di dalam kandang pemeliharaan. Agar ternak memiliki kondisi tubuh yang sehat, perlu dilakukan pencegahan penyakit untuk menjaga lingkungan yang sehat, usaha pencegahan penyakit ternak dapat dilakukan dengan sanitasi maupun vaksinasi kandang. Vaksinasi kandang dapat menggunakan desinfektan berupa antisep, dengan cara penyemprotan didalam maupun disekitar kandang. Tujuannya agar bakteri dan virus yang berada pada lingkungan kandang dan sekitarnya menjadi bersih. 


\section{Pembuatan Tepung Daun Sirsak}

Pembuatan tepung daun sirsak menggunakan daun sirsak menjadi bahan utama, daun sirsak dipetik dari tangkainya. Daun sirsak yang digunakan adalah daun ke 3-7 dari pangkal ranting sampai ke ujung ranting, kemudian dikeringkan dengan cara dianginkan terlebih dahulu tujuanya untuk mengurangi kandungan air yang terdapat pada daun sirsak. Kemudian daun sirsak di oven dengan suhu $60^{\circ} \mathrm{C}$. Apabila melebihi suhu $60^{\circ} \mathrm{C}$ selama 24 jam kandungan zat aktif yang terdapat pada daun sirsak akan berkurang, setelah dioven daun sirsak ditepungkan dengan menggunakan blender.

\section{Pengacakan Perlakuan}

Setiap kandang diberi nomor kemudian dilakukan pengacakan perlakuan pada setiap kandang dengan cara pengundian. Setelah itu dilakukan pengacakan ayam kedalam setiap unit perlakuan yang terdiri dari 24 petak kandang.

\section{Persiapan DOC (Day Old Chick)}

DOC di peroleh dari toko poultry shop di daerah A.Widodo sebanyak 100 ekor. DOC yang digunakan sebanyak 96 ekor. Pertama kali tiba dilokasi penelitian, DOC diberi air minum berupa larutan gula, tujuannya untuk mengembalikan stamina/ kesegaran DOC setelah tenaga habis sewaktu dalam perjalanan. Larutan gula dibuat dengan cara melarutkan gula putih sebanyak $20 \mathrm{~g}$ kemudian di campurkan dengan air sebanyak 1 liter, dicampur sampai homogen. Sebelum dipelihara dilakukan penimbangan terlebih dahulu dengan tujuan untuk mengetahui berat badan awal DOC, kemudian diseleksi untuk mengetahui ayam jantan yang normal dan sehat. DOC yang sudah diseleksi dengan jumlah 96 ekor kemudian ditempatkan pada petakan perlakuan, setiap perlakuan diisi sebanyak 4 ekor DOC. Setelah umur 8 hari kemudian pakan diberikan sesuai perlakuan yang ditentukan. Pemeliharaan DOC dilakukan selama 60 hari.

\section{Pemberian Pakan dan Minum}

Pemberian pakan dan air minum harus seimbang, dalam arti pakan dan minum harus disediakan secara ad libitum. Pemberian pakan dilakukan pada pagi hari,pakan yang diberikan pada pemeliharaan ini adalah aplikasi pakan ransum komersil, jagung, dedak dan tepung daun sirsak sesuai dengan perlakuan.

\section{Penanggulangan Penyakit}

Supaya kondisi ayam selalu dalam keadaan sehat, segar, dan tidak terganggu oleh timbulnya penyakit, maka dilaksanakan pembersihan kandang, seperti serbuk gergaji yang telah basah oleh kotoran ayam harus diganti dengan yang baru. Dan untuk mencegah penyakit dilakukan dengan cara vaksinasi.

\section{Peubah yang Diamati}

Adapun variabel yang diamati dalam penelitian ini adalah bobot potong, bobot gizard, usus halus, dan bobot usus besar.

\section{HASIL DAN PEMBAHASAN}

Hasil analisis keragaman menunjukkan bahwa Pemberian Tepung Daun Sirsak (Annona muricata Linn) dalam Ransum terhadap Sistem Pencernaan Ayam Petelur Jantan (Gallus domesticus) memberikan pengaruh tidak nyata terhadap bobot potong, bobot gizard, bobot usus halus, dan bobot usus besar (Tabel 2).

\section{Pengaruh Pemberian Tepung Daun Sirsak terhadap Bobot Potong}

Berdasarkan analisis ragam diketahui bahwa pengaruh pemberian tepung daun sirsak terhadap bobot potong ayam petelur jantan menunjukkan berpengaruh tidak nyata. Hal ini disebabkan karena adanya cita rasa pahit dalam ransum yang berakibat menurunkan palatabilitas pakan yang diberikan dan dapat menurunkan konsumsi pakan sehingga bobot potong ayam juga menurun. Hal ini sesuai dengan pendapat Purba et al. (2014) menyatakan bahwa pertambahan bobot badan dipengaruhi oleh konsumsi ransum. Jadi secara tidak langsung 
Tabel 2. Data tabulasi pada perlakuan pemberian Tepung Daun Sirsak (Annona muricata Linn) dalam Ransum terhadap Sistem Pencernaan Ayam Petelur Jantan (Gallus domesticus)

\begin{tabular}{llcccccc}
\hline \multirow{2}{*}{ No } & \multirow{2}{*}{ Peubah Yang Diamati } & \multicolumn{7}{c}{ Perlakuan } \\
\cline { 3 - 7 } & & $\mathrm{U} 0$ & $\mathrm{U} 1$ & $\mathrm{U} 2$ & $\mathrm{U} 3$ & $\mathrm{U} 4$ & U5 \\
\hline 1. & Bobot Potong (g) & 413,50 & 435,25 & 425,50 & 414,75 & 405,00 & 410,50 \\
2. & Bobot Gizard (\%) & 3,67 & 3,92 & 3,18 & 3,76 & 3,87 & 3,97 \\
3. & Bobot Usus Halus (\%) & 3,94 & 3,65 & 3,53 & 3,64 & 3,93 & 4,63 \\
4. & Bobot Usus Besar (\%) & 1,38 & 1,26 & 1,43 & 1,27 & 1,56 & 1,39 \\
\hline
\end{tabular}

Keterangan: Angka-angka yang diikuti oleh huruf yang sama pada baris yang sama berarti berbeda tidak nyata pada taraf uji 5\%(huruf kecil). Uji lanjut DMRT pada perlakuan bobot jantung : $\mathrm{U} 1=0,21 \%, \mathrm{U} 2=0,22 \%, \mathrm{U} 3=0,22 \%, \mathrm{U} 4=0,23 \%$, U5 $=0,23 \%$

konsumsi ransum selama penelitian sangat berpengaruh pada bobot hidup ayam yang dihasilkan. Perbedaan bobot potong ayam ini disebabkan oleh perbedaan konsumsi ransum selama penelitian.

Bobot hidup berkaitan dengan pertambahan bobot tubuh Rata-rata persentase bobot potong yang didapat dari hasil penelitian ini berkisar antara405-435,25 g/ekor/minggu. Persentase bobot potong hasil penelitian ini sedikit lebih rendah jika dibandingkan dengan bobot potong ayam jantan pada penelitian Savitri (2010) selama 7 minggu dengan ratarata persentase berkisar antara 610-750 g/ ekor.

Pada perlakuan U1 $(0 \%)$ memperoleh angka tertinggi yaitu 435,25 g/ekor, hal ini disebabkan karena adanya zat-zat makanan/ nutrisi yang terdapat dalam ransum khususnya protein yang diperoleh dari konsumsi pakan, jika konsumsi pakan meningkat maka bobot potong juga meningkat. Hal ini didukung oleh Rasyaf (2004) yang menyatakan bahwa konsumsi ransum merupakan cermin dari masuknya sejumlah unsur nutrien ke dalam tubuh ayam. Selain itu, Blakely dan Blade (2006) menyatakan bahwa tingkat konsumsi ransum akan memengaruhi laju pertumbuhan dan bobot akhir karena pembentukan bobot, bentuk, dan pakan yang dikonsumsi ke dalam tubuh ternak.Sedangkan pada perlakuan U4 (6\%) memperoleh angka terendah yaitu 405 g/ekor, hal ini disebabkan karena tingkat palatabilitas ternak rendah sehingga konsumsi ransum juga rendah, maka pertambahan berat badandan bobot potong pada akhir penelitian ini juga rendah. Hal ini sesuai dengan pendapat Nurhayati (2013) berpendapat bahwa pertumbuhan ayam tergantung dengan kualitas dari ransum yang diberikan. Pendapat ini juga didukung oleh pendapat Hasan et al. (2013) menyatakan bahwa beberapa faktor yang akan mempengaruhi ternak unggas adalah protein ransum dan konsumsi pakan.

\section{Pengaruh Pemberian Tepung Daun Sirsak terhadap Bobot Gizard}

Berdasarkan analisis keragaman diketahui bahwa pengaruh pemberian tepung daun sirsak terhadap bobot gizard ayam petelur jantan menunjukkan berpengaruh tidak nyata. Hal ini disebabkan karena pemberian tepungdaun sirsak dalam ransum tidak berdampak pada perkembangan ampela, pakan yang dicerna tidak mengalami kenaikan, palatabilitas ternak menurun dan konsumsi ransum juga menurun. Hal ini sesuai dengan pendapat Moran et al. (2005) yang menyatakan bahwa pemberian grit dalam pakan danbertambahnya kandungan serat kasar pada pakandapat mempengaruhi kinerja gizard.

Rata-rata persentase bobot gizard yang didapat dari hasil penelitian ini berkisar anatara 3,18 - 3,97\% dari bobot potong. Persentase bobot gizzard hasil penelitian ini sedikit lebih rendah dari pendapat Faishal et al. (2013) yang menggunakan ayam broiler umur 4 minggu yang diberi tepung daun sirsak 
bobot gizzard berkisar antara 3,30 - 4,58 \%.

Pada perlakuan U5 (8\%) memperoleh angka tetinggi yaitu 3,97\%, hal ini disebabkan karena bertambahnya kandungan serat kasar pada tepung daun dalam ransum dapat mempengaruhi kinerja gizzard, sehingga dapat meningkatkan bobot gizzard. Hal ini sesuai dengan pendapat Widodo (2002), yang menyatakan bahwa bobot gizzard dipengaruhi oleh serat kasar yang terdapat dalam ransum, dimana tingginya serat kasar ransum maka gizzard akan lebih berat. Sedangkan pada perlakuan U2 (2\%) memperoleh angka terendah yaitu $3,18 \%$, hal ini disebabkan oleh tingkat konsumsi ransum, konsumsi ransum yang rendah dapat mengakibatkan penipisan pada urat daging gizzard, sehingga ukuran gizzard pun akan semakin kecil. Hal tersebut sesuai dengan pendapat Ade (2002), yang menyatakan bahwa gizard memiliki bobot yang mudah berubah-ubah bergantung pada jenis pakan yang dikonsumsi.

\section{Pengaruh Pemberian Tepung Daun Sirsak terhadap Bobot Usus Halus}

Berdasarkan analisis keragaman diketahui bahwa pengaruh pemberian tepung daun sirsak terhadap bobot usus halus ayam petelur jantan menunjukkan berpengaruh tidak nyata. Hal ini disebabkan karena perkembangan usus halus dipengaruhi oleh kandungan serat kasar dalam ransumyang dikonsumsi oleh ayam. hal ini sesuai dengan pernyataan Ibrahim et al. (2018) yang menyatakan bahwa hasil antar perlakuan yang relative sama dikarenakan enzim pencernaan tidak bekerja secara maksimal.

Rata-rata persentase bobot usus halus ayam pejantan yang diperoleh pada penelitian ini berkisar antara 3,53 - 4,63 $\%$ dari bobot potong. Persentase bobot usus halus hasil penelitian ini sedikit lebih rendah dari pendapat Elfiandra (2007) yang menggunakan itik tegal jantan umur 6 minggu yang diberi tepung daun sirsak dengan persentase bobot usus halus berkisar antara 3,45-4,72\%.
Pada perlakuan U5 (8\%) memperoleh angka tertinggi yaitu $4,63 \%$, hal ini disebabkan karena peningkatan bobot usus halus pada perlakuan U5 lebih panjang dari perlakuan U0, hal ini disebabkan karena pemberian tepung daun sirsak dalam ransum dapat menimbulkan perubahan bobot usus halus, dimana bobot usus halus dapat meningkatkan penyerapan. Hal ini sesuai dengan pendapat Amrullah (2003) yang menyatakan bahwa bobot usus halus diikuti dengan jumlah villi usus dan kemampuan sekresi akan meningkatkan kecernaan dan masuknya zat-zat makanan kedalam tubuh dengan konsumsi tetap. Sedangkan pada perlakuan U2 (2\%) memperoleh angka terendah yaitu $3,53 \%$, hal ini disebabkan oleh jenis ransum yang diberikan. Ransum yangmengandung serat kasar yang rendah akan menimbulkan perubahan ukuransaluran pencernaan sehingga menjadi lebih rendah, lebih pendek dan lebih tipis. Hal ini sesuai dengan pendapat Sturkie (2002) yang menyatakan bahwa unggas yang diberiransum berserat kasar rendah cenderung memiliki saluran pencernaan yang lebih kecil dan dan pendek. Pendapat ini juga didukung oleh Syamsuhaidi (2001) menyatakan bahwa penurunan kadar serat kasar dalam ransum cenderung akan memperkecil usus halus.

\section{Pengaruh Pemberian Tepung Daun Sirsak terhadap Bobot Usus Besar}

Berdasarkan analisis keragaman diketahui bahwa pengaruh pemberian tepung daun sirsak terhadap bobot usus besar ayam petelur jantan menunjukkan berpengaruh tidak nyata. Hal ini disebabkan karena ususbesar tidak mencerna pakan, sehingga kandungan bulatacin pada daun sirsak tidak mempengaruhi bobot usus besar. Hal ini sesuai dengan penelitian Sumiati dan Sumirat (2002) yang menyatakan bahwa usus besar tidak mensekresikan enzim, melainkan hanya terjadi prosespenyerapan air untuk meningkatkan kadar air di dalam sel tubuh serta menjaga keseimbangan air pada unggas.

Rata-rata persentase bobot usus besar yang didapat dari hasil penelitian ini berkisar antara $1,26-1,56 \%$ dari bobot potong. 
Persentase bobot usus besar hasil penelitian ini sedikit lebih rendah dari penelitian Faishal et al. (2013) yang menggunakan ayam umur 6 minggu yang diberi tepung daun sirsak bobot usus besar berkisar antara 1,48-1,87 \%.

Pada perlakuan U4 (6\%) memperoleh angka tertinggi yaitu $1,56 \%$, hal ini disebabkan oleh semakin tinggi serat kasar dalam pakan, maka usus besar akan bekembang karena usus besar berfungsi untuk mencerna serat kasar. Hal tersebut sesuai dengan penelitian Purba dan Prasetyo (2014) yang menyatakan bahwa semakin tinggi kandungan serat kasar dan protein kasar dalam pakan, maka bobot usus semakin meningkat. Sedangkan pada perlakuan U1 $(0 \%)$ memperoleh angka terendah yaitu $1,26 \%$, hal ini disebabkan oleh kecepatan ayam mendapatkan makanan, ayam yang terlambat mendapatkan makanan akan memperoleh nutrisis yang lebih rendah untuk berkembang sehingga memiliki bobot usus halus yang lebih rendah. Hal ini sesuai dengan pendapat Ibrahim et al. (2018) yang menyatakan bahwa pertambahan berat dari usus halus dan usus besar ayam broiler diperoleh dari terpenuhinya kandungan nutrisi pada ransum.

\section{KESIMPULAN}

Berdasarkan hasil penelitian yang telah dilakukan dapat disimpulkan bahwa Pemberian tepung daun sirsak pada taraf $8 \%$ dalam ransum mempengaruhi sistem pencernaan ayam petelur jantan.

\section{DAFTAR PUSTAKA}

Ade, A. 2012. Kesehatan Organ Dalam Unggas. Paduan Bagi Petugas Teknis, Penyuluhan dan Peternak. Kasinus. Yogyakarta.

Adri, D. dan Hersoelistyorini, W. 2013. Antioxidant Activity and Organoleptic Charecteristic of Soursop (Annona muricata Linn.) Leaf tea Based on Variants Time Drying. Jurnal Pangan dan Gizi 04 (07): 1-12.Jakarta.

Amrullah, I. K. 2003. Nutrisi Ayam Broiler. Lembaga Satu Gunung Budi. Bogor.

Anggorodi. R. 2000. Kemajuan Mutahir Dalam Ilmu Makanan Ternak Indonesia. UUI Press. Jakarta.

Blakely, J. dan D. H. Bade. 2006. Ilmu Peternakan. Diterjemahkan oleh Srigandono, Bambang. UGM Press. Yogyakarta

Elfiandra. 2007. Pemberian warna lampu penerangan yang berbeda terhadap organdalam ayam broiler. Fakultas Peternakan. Institut Pertanian Bogor. Bogor.

Faishal, I. J., Djunaidi, I. H. and Sudjarwo, E. 2013. Effect of Addition Mangosteen Peel Powder (Garcinia mangostana. L) to Feed on Carcass and Internal Organs Mojosari Drake. Jurnal Brawijaya 5 (1): 1-10. Jakarta.

Hasan, N. F., U. Atmomarsono, dan E. Suprijatna. 2013. Pengaruh frekuensi pakan pada pemabatasan pakan terhadap bobot tubuh, lemak abdominal, kadar lemak hati ayam broiler. Animal agriculture jornal. 2 (1): 336-343.

Ibrahim, W., R. Mutia, dan Nurhayati. 2018. Penggunaan kulit nanas fermentasi dalam ransum yang mengandung gulma berkhasiat obat terhadap organ pencernaan ayam broiler. jurnal sains peternakan bengkulu 13 (2) : 214-222.

Moran, P. A., D. K. Graner., V. W. Rod Well, and D. W. Martin. 2005. Biokimia (Harper Review of Biochemistry) Ed. 20. Alih Bahasa Dr. Iyan Darmwan. CV. EGC. Jakarta.

Nurhayati. 2013. penampilan ayam pedaging yang mengkonsumsi pakan mengandung kulit nanas disuplementasi dengan yoghurt. Agripet. 13(02) : 1520

Purba, M. dan Prasetyo L. H. 2014. Respon Pertumbuhan dan Produksi Karkas Itik Pedaging EPMP terhadap Perbedaan 
Kandungan Serat Kasar dan Protein dalam Pakan. JITV. Jurnal Brawijaya. 19(3): 220-230. Jakarta.

Rasyaf. 2004. Beternak Ayam Pedaging. Penebar Swadaya. Jakarta.

Rasyaf, M. 2006. Beternak Ayam Pedaging. Cet. Ke-26. Penebar Swadaya. Jakarta.

Rusmiyati, S. 2007. Pengaruh Ekstrak Metanol. Pustaka Baru. Press. Jakarta

Rohmah, N., Tugiyanti, E. dan Roesdiyanto. 2016. Organ Pencernaan, Daun Sirsak, Itik Tegal Jantan. Fakultas Peternakan. Universitas Lampung. Lampung.

Savitri, F. 2010. Pemeliharaan Ayam Jantan Tipe Medium. Fakultas Pertanian. Universitas Lampung. Lampung.

Sudarmono, A. S. 2003. Pedoman Pemeliharaan Ayam Petelur. Kanisius. Yogyakarta.
Sumiati dan Sumirat. 2002. Persentase bobot saluran pencernaan dan organ dalam itik lokal (Anas platyrhyncos) jantan yang diberi berbagai taraf kayambang (Salvina molesta) dalam ransumnya. Jurnal Brawijaya 8 (1) Hal 12-26 Jakarta.

Soeparno. 2005. Ilmu Teknologi daging. Gadjah Mada University Press. Yogyakarta.

Sturkie, P. D. 1976. Avian Physiology. 3rd Edition. Spinger-Verlag. New York.

Syamsuhaidi. 2001. Pedoman Pemeliharaan Ayam Petelur. Program Pascasarjana. Institut Pertanian Bogor. Bogor.

Widodo, W. 2002. Nutrisi dan Pakan Unggas Konstektual. Fakultas Peternakan Perikanan. Universitas Muhammadiyah Malang. Malang. 